\title{
PROPERTIES OF FSW AND MIG WELDED JOINTS OF ALSiMg ALUMINIUM ALLOY
}

\author{
SEJČ Pavol ${ }^{1 *}$, BUČÁNY Martin ${ }^{1}$, ZIFČÁK Peter ${ }^{2}$ \\ ${ }^{I}$ Slovak University of Technology in Bratislava, Faculty of Mechanical Engineering, Institute of Technologies \\ and Materials, Nám. Slobody 17, 81231 Bratislava, Slovakia, e-mail: pavol.sejc@stuba.sk \\ ${ }^{2}$ Welding Research Institute, Račianska 71, 83102 Bratislava, Slovakia
}

\begin{abstract}
Friction Stir Welding (FSW) is one of the modern and constantly evolving technologies of solid state joining and is used for welding a wide range of materials. The main parameters of friction stir welding such as rotational speed of the tool, movement speed and the angle of a tilt are analyzed in this article. 6XXX aluminium alloys have been investigated. The examined mechanical properties of the welds include hardness and strength, which are both important sources of information about quality of welding of the materials used in constructions.
\end{abstract}

KEYWORDS: Friction stir welding, Metal-arc inert gas welding, Al-alloy, Mechanical properties, Friction weldability

\section{Introduction}

Today, aluminium alloys are a key material in the aerospace, automotive, marine, railway and engineering industries [1-4]. Fusion welding of aluminium is not considered a simple standard process due to its high affinity for atmospheric oxygen, which causes rapid oxidation during melting. Other critical properties are the high coefficient of thermal expansion, high thermal and electrical conductivity and the wide solidification temperature range of aluminium and its alloys. These properties generally cause Al alloys to be susceptible to defects during fusion welding, which can lead to degradation of the weld properties. Typical defects in welding $\mathrm{Al}$ and its alloys are: porosity, oxide inclusions, hot cracking and a strength decrease in weld metal (WM) and heat affected zone (HAZ). Primarily, these errors can be prevented by effective gaseous protection of the weld pool and limitation of the heat input to the weld using welding processes with higher energy density [5-9]. Another alternative is the application of pressure solid state welding methods [10-12].

The dominant position here in recent years has been the friction stir welding (FSW) technology, developed in 1991. The development of the technology today makes it possible to weld a number of aluminium alloys with different states of heat treatment [13-17]. Friction welding is solid state welding; therefore, hot cracking of the welded joint is excluded [11].

In the presented work, the influence of selected FSW process parameters during welding of AlSiMg aluminium alloy (type: AW 6005A-T6) on the mechanical properties (strength and hardness) of the welded joint was investigated. The achieved values were compared with the results obtained on welded joints made by the MIG method.

\section{Materials and Methods}

The experimental material was an aluminium alloy EN AW 6005A T6 (AlSiMg), with thicknesses of 3 and $10 \mathrm{~mm}$. All materials were in the state of heat treatment T6, in which solution treatment is carried out at around $530^{\circ} \mathrm{C}$ followed by ageing at temperatures in the 
range $150-180^{\circ} \mathrm{C}$, with a view to achieving precipitation hardening by via $\mathrm{Mg}_{2} \mathrm{Si}$. The chemical composition of the Al alloy used according to EN 573-3 [18] is shown in Table 1.

Tab. 1 Chemical composition of the base plate EN AW 6005A T6 (AlSiMg) according to the standard EN 573-3

\begin{tabular}{|c|c|c|c|c|c|}
\hline Elements & $\mathrm{Si}$ & $\mathrm{Fe}$ & $\mathrm{Cr}$ & $\mathrm{Mn}$ & $\mathrm{Mg}$ \\
\hline Wt. \% & $0,5-0,9$ & $\max .0,35$ & $\max .0,30$ & $\max .0 .5$ & $0,40-0,70$ \\
\hline Elements & $\mathrm{Zn}$ & $\mathrm{Cu}$ & $\mathrm{Ti}$ & $\mathrm{Pb}$ & $\mathrm{Comment}$ \\
\hline Wt. \% & max. 0,20 & max. 0,30 & $\operatorname{max.0,10}$ & $\operatorname{max.0} 05$ & $\begin{array}{c}0,12-0,50 \\
\mathrm{Mn}+\mathrm{Cr}\end{array}$ \\
\hline
\end{tabular}

The values of hardness and mechanical properties required by standard EN 755-2 [19] for the basic experimental material (BM) are summarized in Table 2. The hardness values from the standard are given in HBW units. Hardness measurements on experimental materials were performed in HV 2. Therefore, the conversion of hardness units according to EN ISO 18265 [20] was performed. These values are for guidance only.

Tab. 2 Required values of mechanical properties of the base material EN AW 6005A T6 (AlSiMg) according to the standard EN 755-2

\begin{tabular}{|c|c|c|c|c|c|}
\hline Thickness & Hardness & Tensile & Yield stress & \multicolumn{2}{|c|}{ Elongation } \\
\cline { 5 - 6 } & HBW/(HV10)* & $\begin{array}{c}\text { strength } \mathrm{R}_{\mathrm{m}} \\
(\mathrm{MPa})\end{array}$ & $\begin{array}{c}\mathrm{R}_{\mathrm{p} 0.2} \\
(\mathrm{MPa})\end{array}$ & $\begin{array}{c}\mathrm{A}_{50} \\
(\%)\end{array}$ & $\begin{array}{c}\mathrm{A} \\
(\%)\end{array}$ \\
\hline 3 & $\min .90(95)$ & min. 255 & min. 215 & min. 6 & min. 8 \\
\hline 10 & $\min .85(90)$ & min. 260 & min. 215 & min. 6 & min. 8 \\
\hline
\end{tabular}

* hardness value HV 10 converted from HBW value

The aluminium base alloys (6xxx series) are highly crack sensitive because the majority of these alloys contain approximately $1,0 \%$ magnesium silicide $\left(\mathrm{Mg}_{2} \mathrm{Si}\right)$, which falls close to the

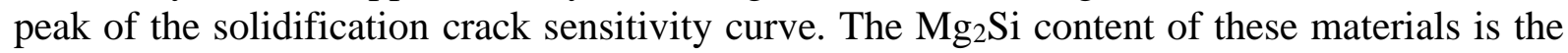
primary reason why there are no 6xxx series filler alloys.

During arc welding, the cracking tendency of these alloys is adjusted to acceptable levels by the dilution of the base material with excess magnesium (by the use of the $5 \mathrm{xxx}$ series Al$\mathrm{Mg}$ filler alloys) or excess silicon (by the use of the 4xxx series Al-Si filler alloys) [21].

For this reason, aluminium alloys $\mathrm{Al} 5087$ and $\mathrm{Al} 4043$ (for both base material thicknesses) were used as filler materials in MIG welding. The indicative chemical composition of the used filler wire with a diameter of $\varnothing=1,2 \mathrm{~mm}$ and selected mechanical properties of the weld metal are in Table 3 and 4.

OK Autrod 5087 is a continuous solid wire suitable for welding aluminium alloys with up to $5 \% \mathrm{Mg}$ and alloys where a higher tensile strength is required. The alloying element $\mathrm{Zr}$ produces improved resistance to hot cracking during solidification [22]. OK Autrod 4043 is one of the most widely used welding and brazing alloys and can be classed as a general purpose filler alloy. The silicon additions result in improved fluidity (wetting action) to make the alloy a preferred choice by welders. The alloy is not sensitive to weld cracking and produces bright and almost smut free welds. Alloy is non-heat treatable [23].

Selected properties of welded joints of EN AW 6005 material with different thickness (3 and $10 \mathrm{~mm}$ ) welded by MIG and FSW technology were compared. The designation of the samples welded by the MIG method according to the thickness of the welded and filler material is given in Table 5. In the case of FSW welding, no filler materials were used. 
Tab. 3 Chemical composition of the filler wires [22, 23]

\begin{tabular}{|c|c|c|c|c|c|c|c|c|c|c|}
\hline Type - mark & \multicolumn{10}{|c|}{ Element in wt. \% } \\
\cline { 2 - 11 } & $\mathrm{Mn}$ & $\mathrm{Si}$ & $\mathrm{Cr}$ & $\mathrm{Al}$ & $\mathrm{Cu}$ & $\mathrm{Ti}$ & $\mathrm{Fe}$ & $\mathrm{Mg}$ & $\mathrm{Zn}$ & $\mathrm{Zr}$ \\
\hline $\begin{array}{c}\text { OK Autrod } \\
5087\end{array}$ & 0,8 & 0,04 & 0,08 & Rem & 0,01 & 0,08 & 0,12 & 4,7 & 0,01 & 0,11 \\
\hline $\begin{array}{c}\text { OK Autrod } \\
4043\end{array}$ & 0,01 & 5,0 & - & Rem & 0,02 & 0,01 & 0,14 & - & 0,01 & - \\
\hline
\end{tabular}

Tab. 4 Selected properties of filler metal. Condition: as welded [22, 23]

\begin{tabular}{|c|c|c|c|}
\hline \multirow{2}{*}{ Type } & \multicolumn{3}{|c|}{ Typical tensile properties } \\
\cline { 2 - 4 } & $\begin{array}{c}\text { Tensile strength } \\
(\mathrm{MPa})\end{array}$ & $\begin{array}{c}\text { Yield strength } \\
(\mathrm{MPa})\end{array}$ & $\begin{array}{c}\text { Elongation } \\
(\%)\end{array}$ \\
\hline OK Autrod 5087 & 280 & 130 & 30 \\
\hline OK Autrod 4043 & 124 & 55 & 18 \\
\hline
\end{tabular}

Tab. 5 Marking of experimental samples welded by the MIG method according to the thickness of the base metal and filler wire used.

\begin{tabular}{|c|c|c|}
\hline Sample No. & $\begin{array}{c}\text { BM } \\
\text { thickness }\end{array}$ & Filler wire \\
\hline M35 & 3 & OK Autrod 5087 \\
\hline M34 & 3 & OK Autrod 4043 \\
\hline M105 & 10 & OK Autrod 5087 \\
\hline M104 & 10 & OK Autrod 4043 \\
\hline
\end{tabular}

MIG welding was realized using a welding current power source of type Fronius TransPuls Synergic 5000. Before welding base material was preheated to a temperate between 100 and $120^{\circ} \mathrm{C}$. The MIG welding parameters are listed in Table 6 . Sheets with a thickness of $3 \mathrm{~mm}$ were single pass welded, sheets with a thickness of $10 \mathrm{~mm}$ triple pass.

Tab. 6 MIG welding process parameters

\begin{tabular}{|c|c|c|c|}
\hline Weld layer & \multicolumn{3}{|c|}{ Welding parameters } \\
\hline & Current (A) & Voltage $(\mathrm{V})$ & Speed $\left(\mathrm{cm} \cdot \mathrm{min}^{-1}\right)$ \\
\hline 1. & $240 \div 250$ & $21,8 \div 22,3$ & $110 \div 120$ \\
\hline 2. & $230 \div 240$ & $21,8 \div 22,3$ & $95 \div 105$ \\
\hline 3. & $215 \div 225$ & $23,5 \div 24,0$ & $70 \div 75$ \\
\hline
\end{tabular}

Linear FSW welds were made using two tools with different process parameters, depending on the thickness of the base material (Figure 1). Welding parameters were selected experimentally based on visual inspection. The welding speed ranged from 600 to 1400 $\mathrm{mm} . \mathrm{min}^{-1}$, with tool rotating speed in the range from 1000 to $1500 \mathrm{rpm}$. The welds were made in the tool tilt angle $0^{\circ}$ (position perpendicular to the weld) and with a $3^{\circ}$ deflection. With tool tilt angle $0^{\circ}$ position, it is possible to weld in the direction of the $\mathrm{X}$ (forward) and $\mathrm{Y}$ (lateral) directions. In the $3^{\circ}$ position, the axis of the welding tool is tilted from the welding direction at an angle of $93^{\circ}$. With this tool position, welding is only possible in one direction (X axis), as welding in another direction would be impractical and inefficient. Welding tools with a convex shoulder and a conical pin were used for the production of FSW welded joints. The optimized welding parameters are listed in Table 7. The goal of optimization was to eliminate 
the formation of: tunnel defects, kissing bond defects, voids, crack-line root defects and flash defects.

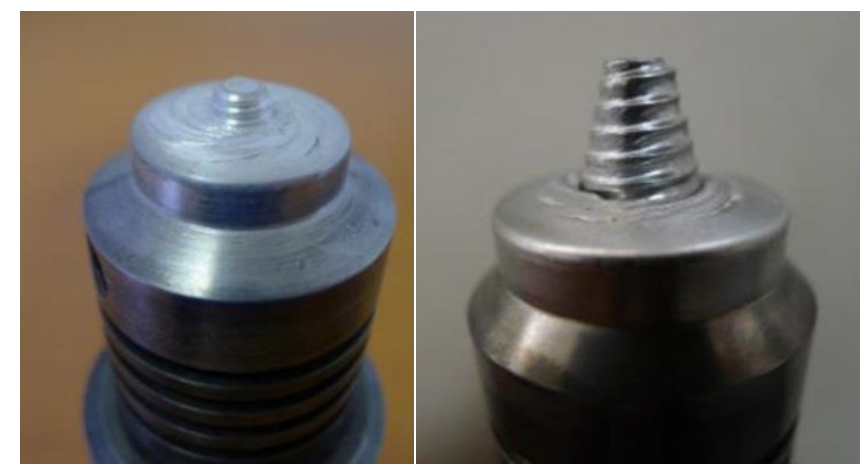

a)

b)

Fig. 1 Design of the FSW tools (tapered with threads) for welding base material: a) $3 \mathrm{~mm}$, b) $10 \mathrm{~mm}$ of thickness.

Tab. 7 Optimized FSW parameters

\begin{tabular}{|c|c|c|c|c|}
\hline \multirow{2}{*}{$\begin{array}{c}\text { Sample } \\
\text { No. }\end{array}$} & \multirow{2}{*}{$\begin{array}{c}\text { BM } \\
\text { thickness } \\
(\mathrm{mm})\end{array}$} & \multicolumn{3}{|c|}{ FSW Parameters } \\
\hline & & $\begin{array}{c}\text { Rotation } \\
\text { speed (RPM) }\end{array}$ & $\begin{array}{l}\text { Welding speed } \\
\left(\mathrm{mm} \cdot \mathrm{min}^{-1}\right)\end{array}$ & $\begin{array}{c}\text { Tool tilt angle } \\
\left({ }^{\circ}\right)\end{array}$ \\
\hline 23 & 3 & 1500 & 1400 & 3 \\
\hline 24 & & 1500 & 1000 & 3 \\
\hline 4 & 10 & 1000 & 600 & 0 \\
\hline 27 & & 1500 & 1000 & 3 \\
\hline
\end{tabular}

\section{Results and discussion}

From the comparison of FSW parameters, it is clear that the $3^{\circ}$ tool tilt angle allows the application of higher welding speeds (Table 7). In addition, the tool angle of $3^{\circ}$ formed a smoother weld surface with minimal excessive flash on the retreating side (RS) of the weld (Figure. 2 and 3). This was due to the use of a tilt, with a narrow gap under the leading side of the tool shoulder zone and no sliding problem above the welding line, and the trailing side of the welding tool was in constant contact with the welded material. In this case, the excess material extruded into the sides of the weld was moved in front of the tool, which further processed it.

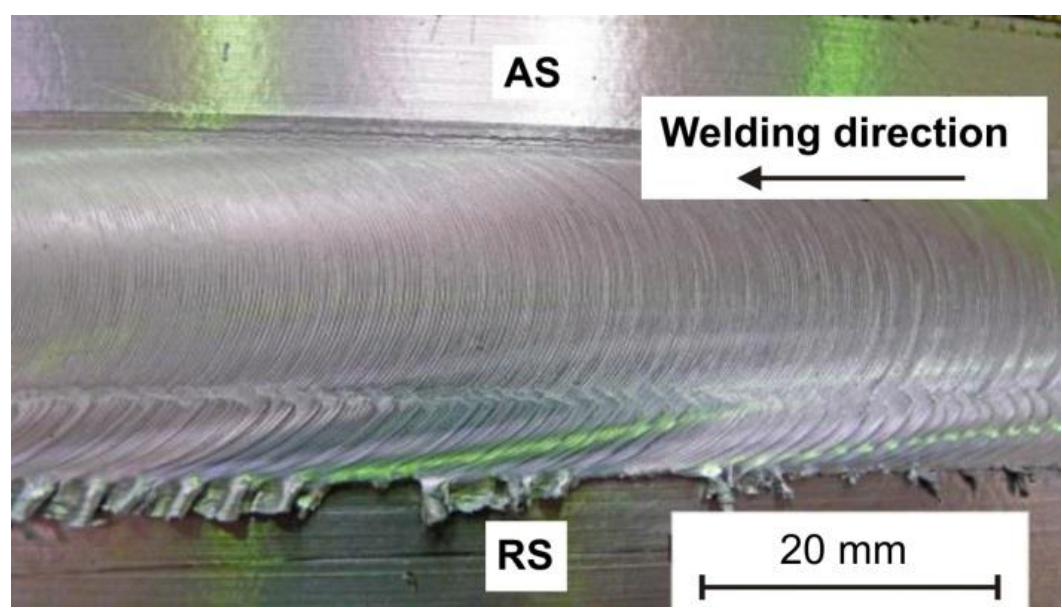

Fig. 2 Upper surface appearance of FSW weld sample No. 4 (see Table 7): $\mathrm{RS}$ - retreating side, AS - advancing side. 


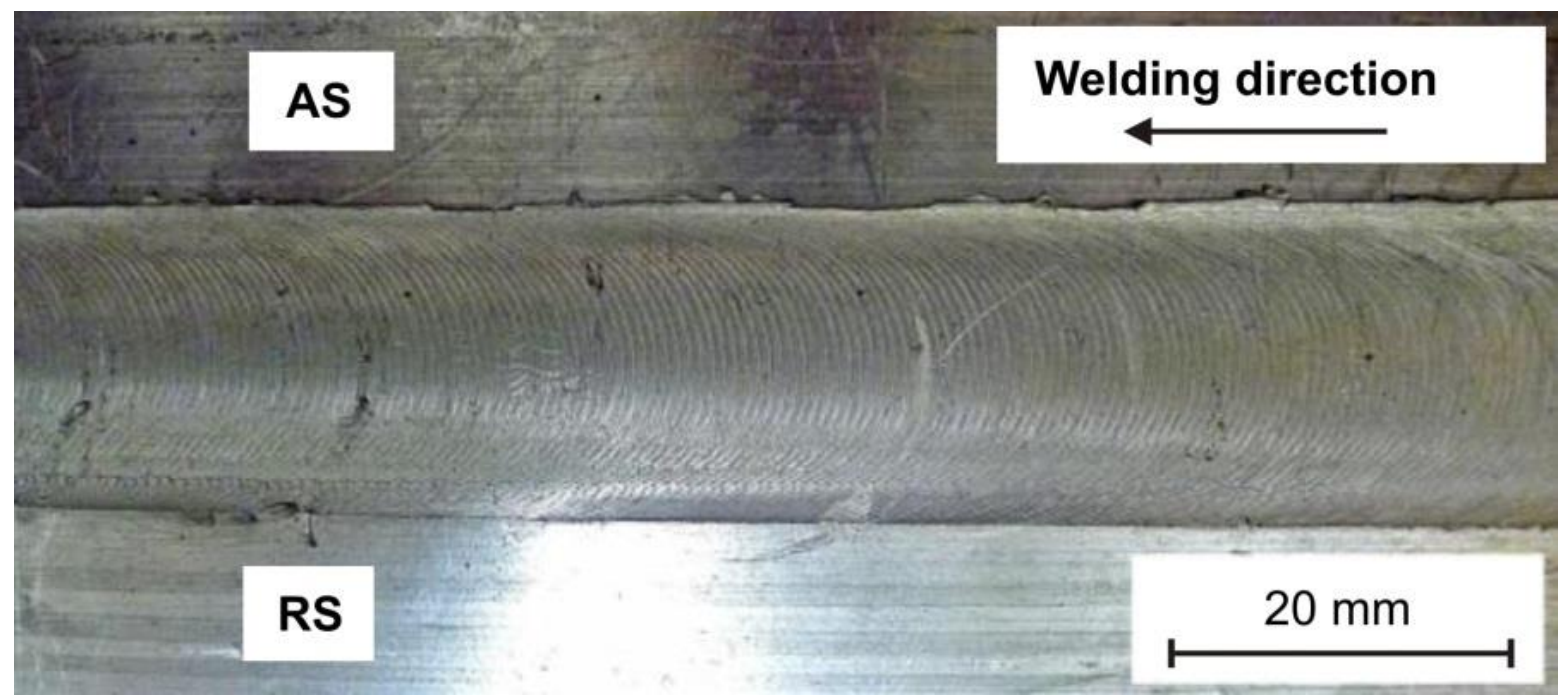

Fig. 3 Upper surface appearance of FSW weld sample No. 27 (see Table 7).

Visual (VT), capillary (PT) and X-ray (RT) non-destructive testing was performed on FSW and MIG welds. Most of the inspected welds were satisfactory (Table 8). RT tests of joints welded by MIG technology of both thicknesses of the base material using the additional material OK Autrod 4043 showed negative results. The results of the tensile strength test and the bend test of FSW and MIG welds are summarized in Table 8 together with the required values according to the standard EN $755-2$ [19]. Table 8 also shows the minimum weld strength $\mathrm{R}_{\mathrm{m}}(\mathrm{WJ})_{\min }$. calculated using the standard EN ISO 25239-4 [24] according to equation:

$$
R_{m}(W J)_{\min .}=R_{m}(B M)_{\min .} \times 0,7
$$

where $\mathrm{R}_{\mathrm{m}}(\mathrm{BM})_{\min }$ is minimum strength of the base material given by the standard EN $755-2$ [13], value 0.7 is a joint efficiency.

The results of measuring the hardness of FSW and MIG welds of the material EN AW $6005 \mathrm{~A}$ - T6 with a thickness of $10 \mathrm{~mm}$ are summarized graphically in Figure 4. For comparison, the hardness profile was measured separately on the root side and separately on the face (cover) side of the welded joint. The hardness of the welded joint on a sheet with a thickness of $3 \mathrm{~mm}$ is shown in Figure 5.

The results of hardness measurements show the following:

a) The widest HAZ area was recorded in MIG welds.

b) FSW weld No.4 (welding speed $600 \mathrm{~mm}^{\mathrm{min}} \mathrm{m}^{-1}$ ) has a wider HAZ than weld No.27 welded at a higher welding speed (1000 mm. $\left.\mathrm{min}^{-1}\right)$, see Table 7.

c) On the retreating side (RS) of all FSW welds, the HAZ width is slightly larger than on the advancing side (AS).

d) The weld metal (WM) of the MIG joint made with the OK Autrod 4043 filler wire reached only half the value of the base metal $(\mathrm{BM})$ hardness, while no differences were observed between the hardness measured in the root and face side of the joint. This fact results from the mechanical properties of the filler material used (see Table 4). An equally significant decrease in hardness was also recorded in the HAZ adjacent to the weld metal.

e) The root side of the joint made with OK AUTROD 5087 filler material also had the same hardness (about 50 HV 2) as the weld metal made with OK Autrod 4043 filler material. In contrast, the cover layer showed increased hardness at 60 to $64 \mathrm{HV}$ 2. The differences 
between the hardness of the root and face layer of the MIG weld joint made with the filler wire OK AUTROD 5087 are caused by the additional heat treatment of the root by thermal cycles during the welding of further layers of the weld.

f) A decrease in WM hardness up to the level of 50\% of the hardness of the base material was also observed on FSW welded joints. Using the experimental welding parameters (see Table 7), more pronounced differences between the root hardness and the top of the weld were noted only when using a lower welding speed. As by MIG welded joints, the HAZ hardness show minimal values (at the weld metal hardness level) in the area adjacent to the WM.

Tab. 8 Results of mechanical properties of FSW and MIG welding joints of material EN AW 6005A - T6

\begin{tabular}{|c|c|c|c|c|c|c|c|}
\hline \multirow{3}{*}{$\begin{array}{l}\text { BM } \\
\text { thickness } \\
(\mathrm{mm})\end{array}$} & \multirow{2}{*}{\multicolumn{2}{|c|}{ Welding joint }} & \multicolumn{5}{|c|}{ Properties of welding joint } \\
\hline & & & \multicolumn{2}{|c|}{$\begin{array}{c}\text { Measured values } \\
\text { (tensile strength } \\
\text { test) }\end{array}$} & $\begin{array}{l}\text { Standard } \\
\text { EN 755-2 }\end{array}$ & \multicolumn{2}{|c|}{ Evaluation } \\
\hline & $\begin{array}{l}\text { Welding } \\
\text { method }\end{array}$ & $\begin{array}{c}\text { Sample } \\
\text { No. }\end{array}$ & $\begin{array}{l}\text { Tensile } \\
\text { strength } \\
(\mathrm{MPa})\end{array}$ & $\begin{array}{l}\text { Fracture } \\
\text { location }\end{array}$ & $\begin{array}{c}\text { Tensile } \\
\text { strength } \\
(\mathrm{MPa})\end{array}$ & $\begin{array}{l}\text { Calculated min. } \\
\text { strength (in } \\
\text { MPa) according } \\
\text { to EN ISO } \\
25239-4\end{array}$ & $\begin{array}{l}\text { Bend } \\
\text { test } \\
\text { result }\end{array}$ \\
\hline \multirow[t]{7}{*}{3} & \multirow[t]{3}{*}{ FSW } & \multirow[t]{2}{*}{24} & 201 & WM & \multirow[t]{7}{*}{$\min .255$} & \multirow[t]{7}{*}{178,5} & $\sqrt{ }$ \\
\hline & & & 201 & WM & & & \\
\hline & & 23 & - & - & & & $\checkmark$ \\
\hline & \multirow[t]{4}{*}{ MIG } & \multirow[t]{2}{*}{ M35 } & 179 & WM & & & \multirow[t]{2}{*}{$\checkmark$} \\
\hline & & & 179 & HAZ & & & \\
\hline & & \multirow[t]{2}{*}{ M34 } & 187 & WM & & & $\checkmark$ \\
\hline & & & 184 & WM & & & $\checkmark$ \\
\hline \multirow[t]{8}{*}{10} & \multirow[t]{4}{*}{ FSW } & \multirow[t]{2}{*}{4} & 218 & HAZ & \multirow[t]{8}{*}{$\min .260$} & \multirow[t]{8}{*}{182} & \multirow[t]{2}{*}{$\checkmark$} \\
\hline & & & 220 & HAZ & & & \\
\hline & & \multirow[t]{2}{*}{27} & 222 & HAZ & & & \multirow[t]{2}{*}{$\checkmark$} \\
\hline & & & 224 & HAZ & & & \\
\hline & \multirow[t]{4}{*}{ MIG } & \multirow[t]{2}{*}{ M105 } & 204 & HAZ & & & \multirow[t]{2}{*}{$\checkmark$} \\
\hline & & & 205 & HAZ & & & \\
\hline & & \multirow[t]{2}{*}{ M104 } & 211 & WM & & & \multirow[t]{2}{*}{$x$} \\
\hline & & & 212 & WM & & & \\
\hline
\end{tabular}

BM - base metal, WM - weld metal, HAZ - heat affected zone,

$\checkmark$ - satisfactory, $x$ - unsatisfactory 


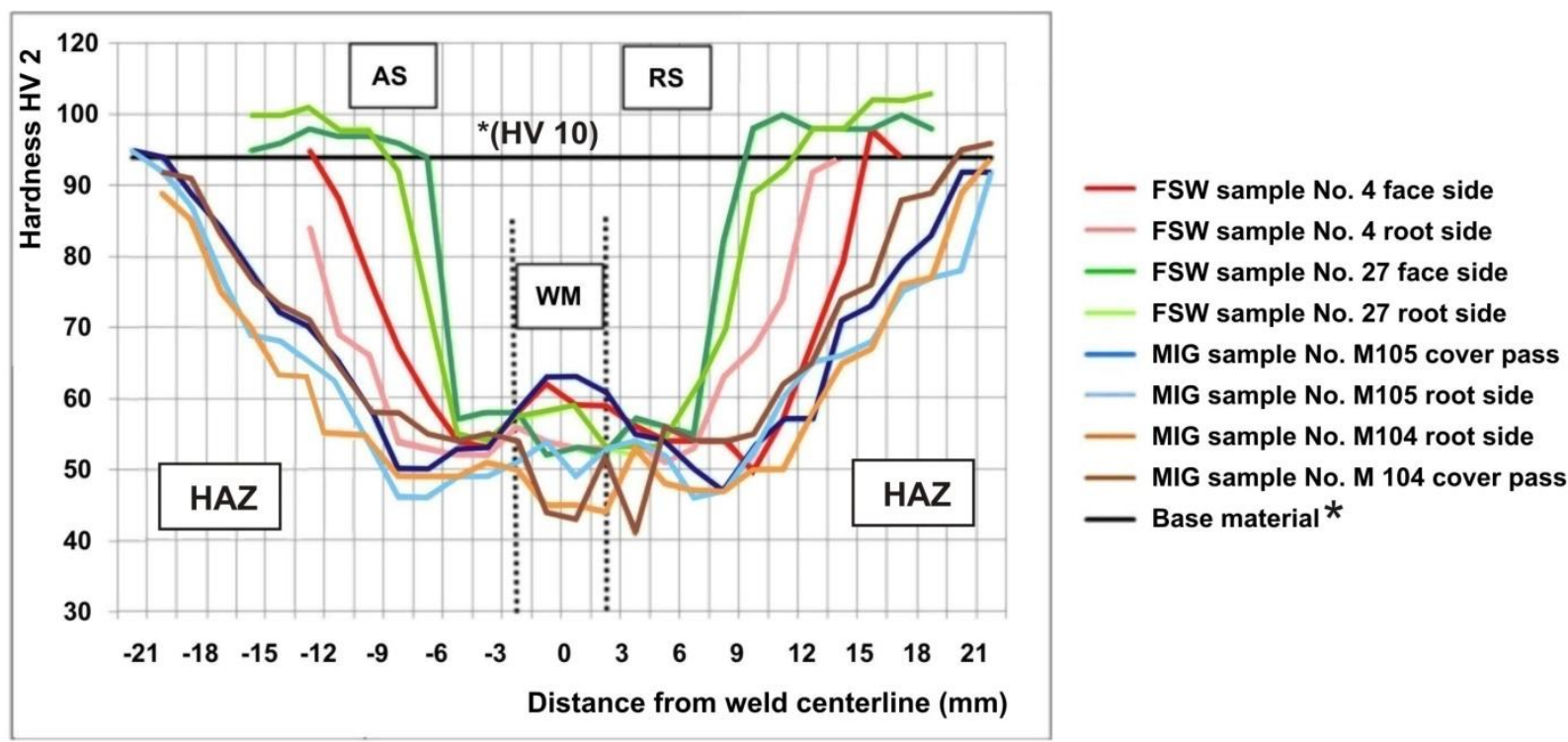

Fig. 4 Hardness profiles of FSW and MIG welded joints on sheets with a thickness of $10 \mathrm{~mm}$

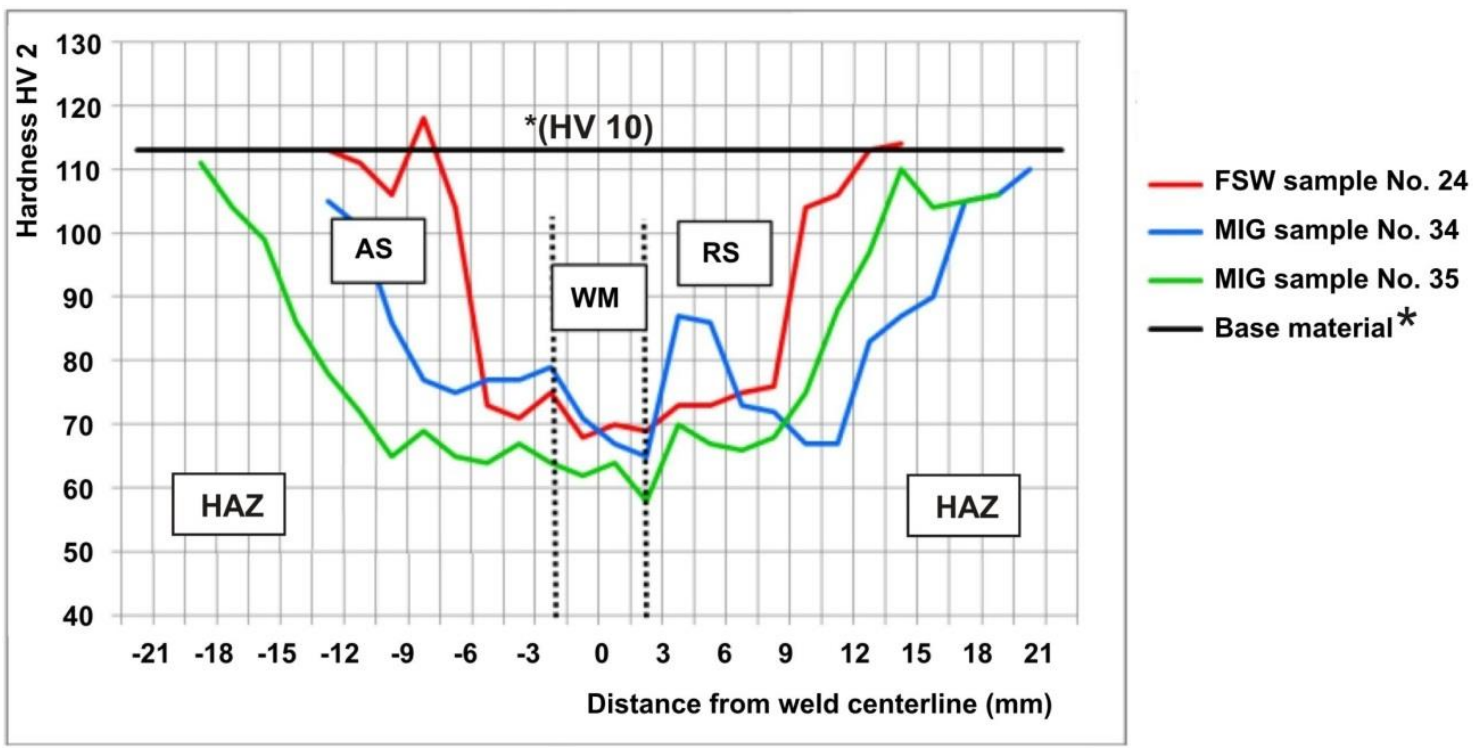

Fig. 5 Hardness profiles of FSW and MIG welded joints on sheets with a thickness of $3 \mathrm{~mm}$

The course of hardness in welded joints for materials with a wall thickness of $3 \mathrm{~mm}$ (Figure 5) is similar to the case of the base metal with a thickness of $10 \mathrm{~mm}$. The hardness gradually decreases from the base material towards the weld, reaching its minimum (60 to 65 HV 2) in the WM. The width of the HAZ with the maximum decrease in hardness (compared to the hardness of the base material) also reaches the same values as when welding sheets with a thickness of $10 \mathrm{~mm}$.

The results of the structural analysis of FSW and MIG welds are documented in Figure 6 to Figure 11. 


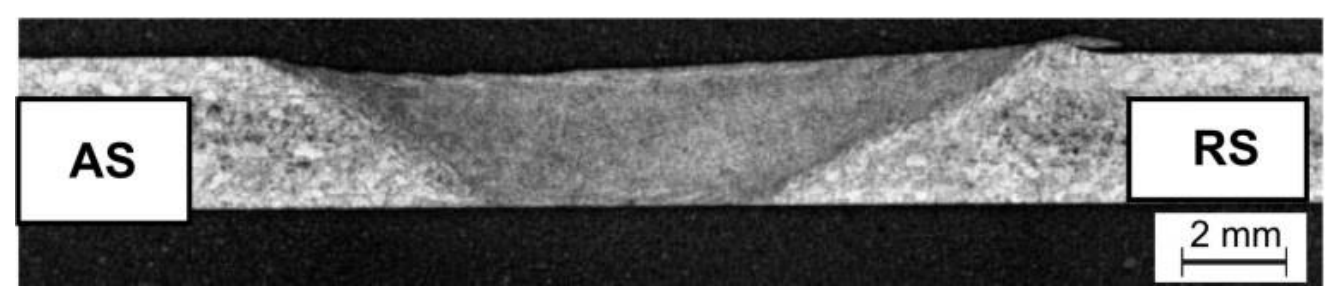

Fig. 6 Structure of FSW weld on $3 \mathrm{~mm}$ thick sheet metal (sample No. 23)

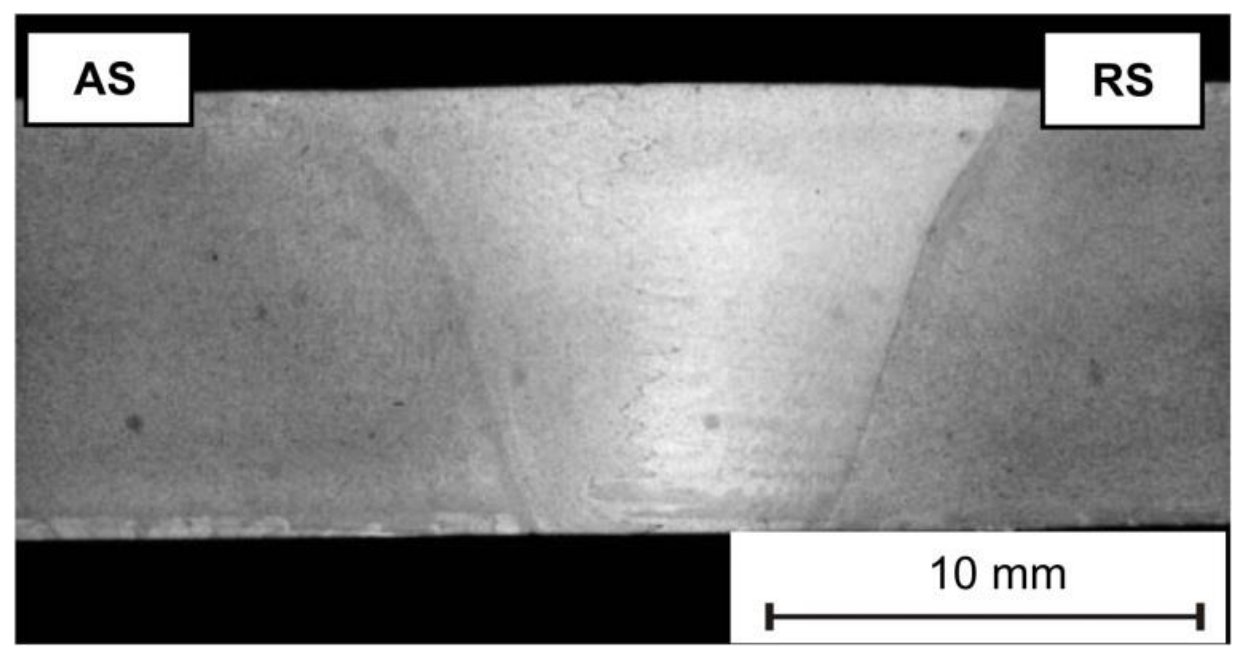

Fig. 7 Structure of FSW weld on $10 \mathrm{~mm}$ thick sheet metal (sample No. 4)

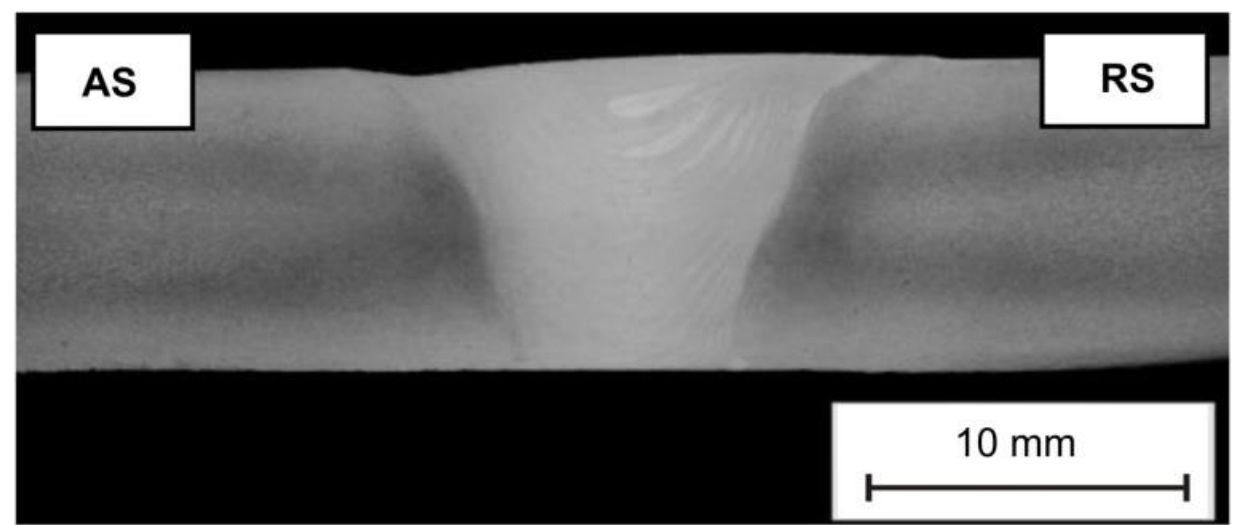

Fig. 8 Structure of FSW weld on $10 \mathrm{~mm}$ thick sheet metal (sample No. 27)

The structure of the FSW welded joints in Figures 6 to 8 is sound, without defects (without the presence of voids, cracks, tunnel defects, inclusions). 


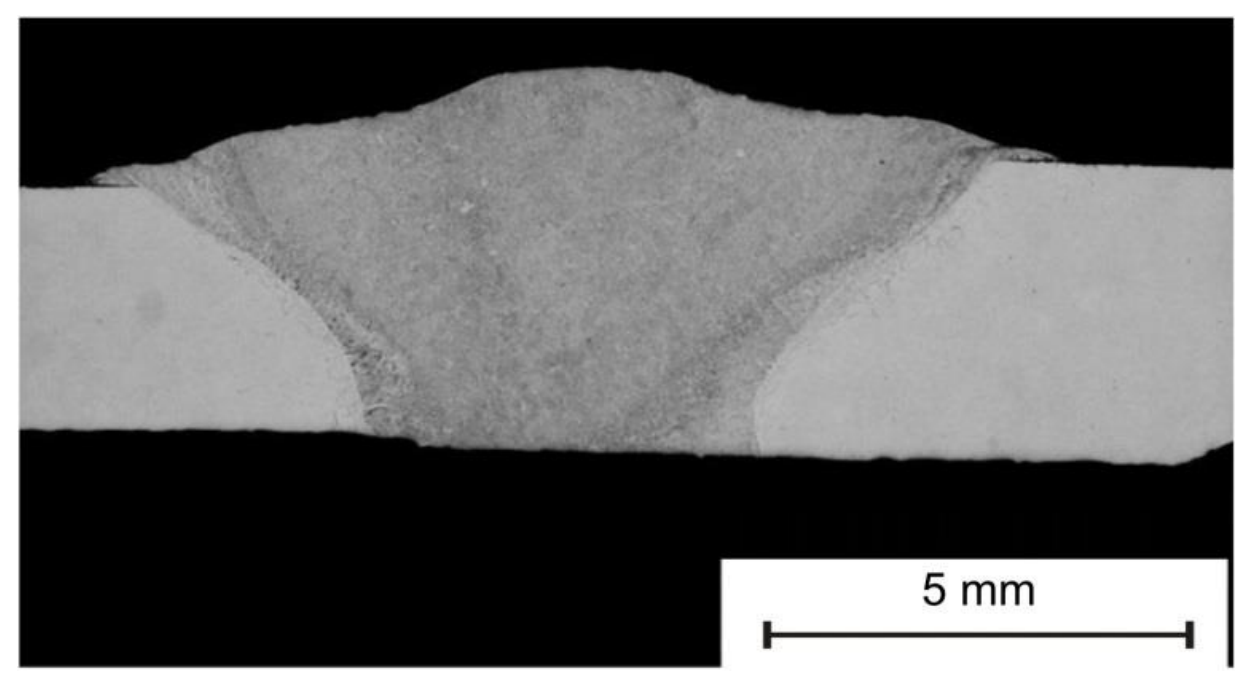

Fig. 9 Structure of MIG weld on $3 \mathrm{~mm}$ thick sheet metal made using OK AUTROD 5087 filler wire (sample No. M35)

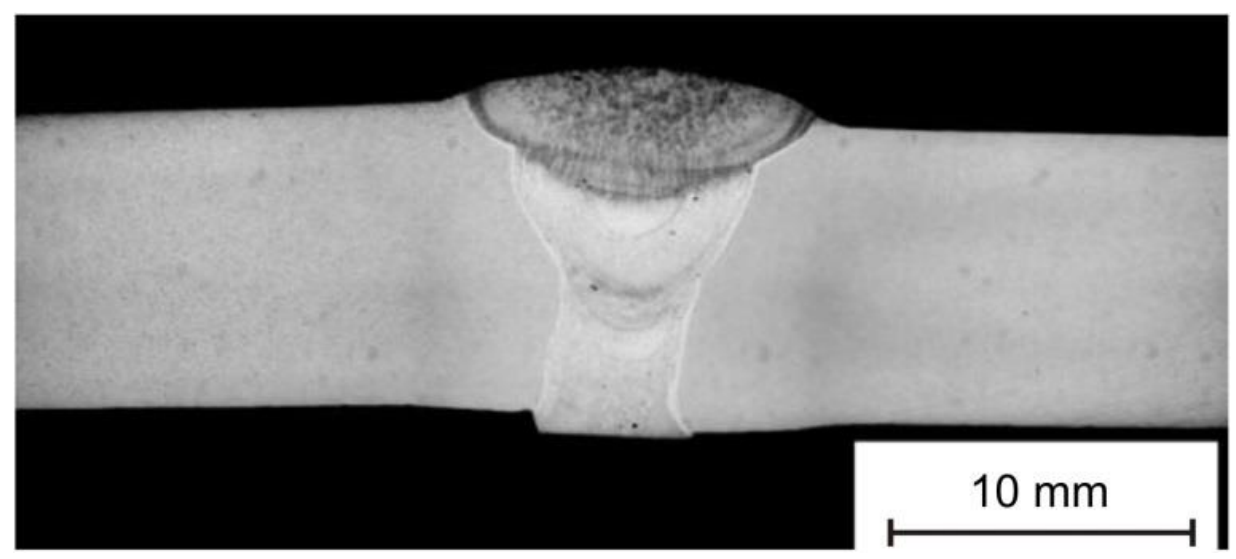

Fig. 10 Structure of MIG weld on $10 \mathrm{~mm}$ thick sheet metal made using OK AUTROD 5087 filler wire (sample No. M105)

Both MIG weld joints welded with the Ok Autrod 5087 filler wire, shown in Figure 9 and 10, are from a structural point of view, sound without cracks, cavities and impurities.

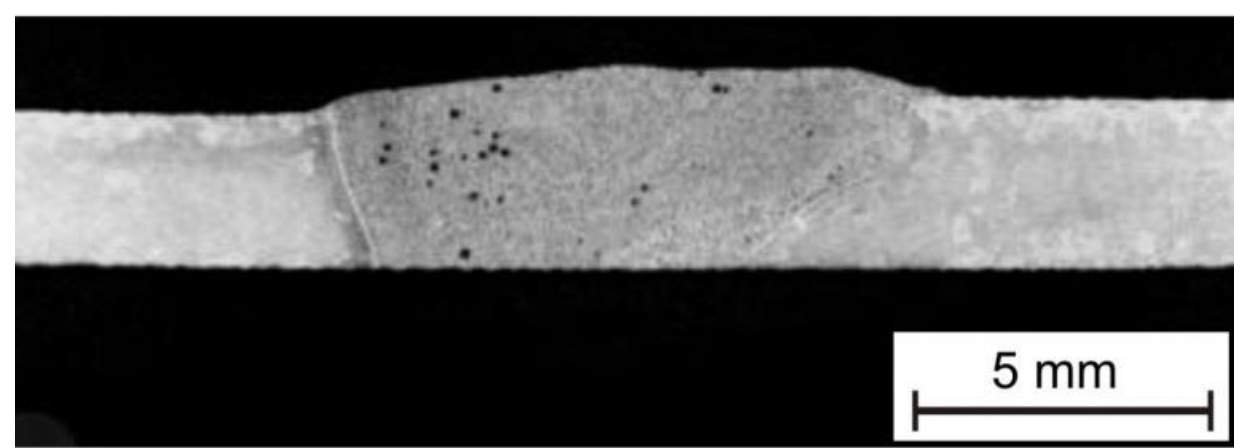

Fig. 11 Structure of MIG weld on $3 \mathrm{~mm}$ thick sheet metal made using OK AUTROD 4043 filler wire (sample No. M34)

The welded joint in Figure 11 made by the MIG method with the filler wire OK Autrod 4043 contains pores. The pore size is in the range of $0,05-0,17 \mathrm{~mm}$.

Material EN AW 6005 A T6 is an alloy especially suitable for welding with FSW technology. It is characterized by a wide lobe diagram of welding parameters, due to which sound welds are formed. Identification of optimal welding parameters by joining a metal sheet 
$10 \mathrm{~mm}$ of thickness was realized in the range of welding speeds $300 \mathrm{~mm} \cdot \mathrm{min}^{-1}$ up to 1000 mm. min ${ }^{-1}$ with a tool rotation speed of 1000 to $1500 \mathrm{rpm}$. In the case of a thin sheet $-3 \mathrm{~mm}$ thickness, it was possible to weld at a significantly higher welding speed of $1400 \mathrm{~mm} \cdot \mathrm{min}^{-1}$ (without presence of defects). In this case, the ratio of tool rotation speed and welding speed is approx. 1:1.

The strength of FSW welded joints is about approx. 5 to $10 \%$ higher than the strength of MIG welded joints. FSW welds are sound and free of cracks, cavities and inclusions. MIG welds welded with OK Autrod 4043 filler material were unsatisfactory from the point of view of RT tests and bend tests. Cavities and pores were present in the welds.

Regarding hardness measurements in all welded joints, a decrease in hardness with a local minimum in the HAZ area or WM was observed. The overall decrease in hardness in MIG welds was greater than in FSW welds. Measurements showed that the heat generated during FSW welding is unevenly distributed. A greater thermal effect was recorded on the RS side of the weld in the form of a wider HAZ compared to the AS side of the weld.

\section{CONCLUSION}

The measured results show the following facts:

a) From the point of view of the RT test, MIG welds welded using the filler material OK Autrod 4043 did not pass. The other weld joints were sound from the point of view of NDT tests.

b) All tested weld joints passed the tensile strength test as well as the bend test, with the exception of the MIG sample on a $10 \mathrm{~mm}$ thick sheet metal welded with the OK Autrod 4043 filler material (sample M104), which did not pass the bend test.

c) The strength of FSW welded joints is approximately 5 to $10 \%$ higher than the strength of MIG welded joints made with selected types of filler materials. At ideal parameters, the welds retain $80 \div 85 \%$ of the strength of the base material.

d) In all weld joints, a decrease in hardness from BM towards the weld was observed, with a local minimum in the HAZ area or WM area. The overall decrease in hardness was greater in MIG welds than in FSW welds.

Based on the results, it is recommended to apply welding by the FSW method to the welding of materials EN AW 6005A (AlSiMg) with the parameters given in Table 7.

\section{REFERENCES}

[1] Fridlyander, I. N., Sister, V. G., Grushko, O. E., Berstenev, V. V., Sheveleva, L. M., Ivanova, L. A. "Aluminum Alloys: Promising Materials in the Automotive Industry", Metal Science and Heat Treatment, September 44, pp. 365 - 370, 2002.

[2] Rambabu, P., Eswara Prasad, N., Kutumbarao, V. V., Wanhill, R. J. H. "Volume 1: Aerospace Materials Aluminium", In: Prasad, N. E., Wanhill, R. (Eds.) Alloys for Aerospace Applications, Aerospace Materials and Material Technologies, Springer Verlag, pp. 29 - 52, 2017. DOI: 10.1007/978-981-10-2134-3_2

[3] Skillingberg, M., Green, J. "Aluminum Applications in the Rail Industry", Light Metal Age 65, pp. 8 - 13, 2007. ISSN 0024-3345

[4] Heinz, A., Haszler, A., Keidel, C., Moldenhauer, S., Benedictus, R., Miller, W. S. "Recent development in aluminium alloys for aerospace applications", Materials Science and Engineering: A280, pp. 102 - 107, 2000. ISSN: 0921-5093. 
[5] Mathers, G. "Welding of Aluminium and its Alloys", $1^{\text {st }}$ Edn., Woodhead Publishing, USA, 2002. ISBN: 978-1-855-73567-5

[6] Kou, S. "Welding metallurgy", $2^{\text {nd }}$ Edn., John Willey and Sons, 2003. DOI: 10.1002/0471434027

[7] Schubert, E., Klassen, M., Zerner, I., Walz, C., Sepold, G. 'Light-weight structures produced by laser beam joining for future applications in automobile and aerospace industry", J. of Materials Processing Technology 115 (1), pp. 2 - 8, 2001. DOI: 10.1016/S0924-0136(01)00756-7

[8] Mandal, N. R. 2005: Aluminium welding, $2^{\text {nd }}$ Edn., New Delhi, Narosa Publishing House, 2005. ISBN 8173196370.

[9] Sejč, P., Világoš, T. "FEM simulation of thermal cycles during laser welding of aluminium", Strojnícky časopis - Journal of Mechanical Engineering 68 (1), pp. 89 94, 2018. DOI: $10.2478 /$ scjme-2018-0009

[10] Threadgill, P. L., Leonard, A. J., Shercliff, H. R., Withers, P. J. ’Friction stir welding of aluminium alloys", J. International Materials Reviews 54 (2), pp. 49 - 93, 2009. DOI: $10.1179 / 174328009 X 411136$

[11] Adamowski J., Szkodo M. "Friction Stir Welds of Aluminum alloy AW6082-T6", J. of Achievements in Materials and Manufacturing Engineering 20, pp. 403 - 406, 2007. ISSN: $1734-8412$

[12] XIAOFEI SHENG, X., LI, K., WU, W., YANG, Y., LIU, Y., ZHAO, Y., HE, G. "Microstructure and Mechanical Properties of Friction StirWelded Joint of an Aluminum Alloy Sheet 6005A-T4", Metals 9 (1152), pp. 1 - 11, 2019. DOI: 10.3390/met9111152

[13] Jančo, R., Écsi, L., Élesztős, P. "FSW numerical simulation of aluminium plates by SYSWELD - Part I", Strojnícky časopis - Journal of Mechanical Engineering 66 (1), pp. 47 - 52, 2016. DOI: 10.1515/scjme-2016-0010

[14] Jančo, R., Écsi, L., Élesztős, P. "FEM simulation of thermal cycles during laser welding of aluminium", Strojnícky časopis - Journal of Mechanical Engineering 66 (2), pp. 29 - 36, 2016. DOI: $10.1515 /$ scjme-2016-0016

[15] Fratini, L., Buffa, G. "CDRX modelling in friction stir welding of aluminium alloys", International Journal of Machine Tools \& Manufacture 45, pp. 1188 - 1194, 2005. DOI: 10.1016/j.ijmachtools.2004.12.001

[16] Vural, M., Ogur, A., Cam, G., Ozarpa, C. "On the friction stir welding of aluminium alloys EN AW 2024-0 and EN AW 5754-H22", Archives of Materials Science and Engineering 28 (1), pp. 49 - 54, 2007. ISSN 1897-2764

[17] Cavaliere, P., Cerri, E., Squillace, A. "Mechanical response of 2024-7075 aluminium alloys joined by Friction Stir Welding", Journal of Materials Science 40, pp. 3669 3676, 2005. ISSN 0022-2461

[18] EN 573-3:2019, Aluminium and aluminium alloys - Chemical composition and form of wrought products - Part 3: Chemical composition and form of products

[19] EN 755-2:2016, Aluminium and aluminium aaloys - Extruded rod/bar, tube and profiles. Part 2: Mechanical properties.

[20] EN ISO 18265:2013, Metallic materials - Conversion of hardness values 
[21] Kah, P., Hiltunen, E., Martikainen, J. "Investigation of Hot Cracking in the Welding of Aluminium Alloys (6005 \& 6082)", In: 63 ${ }^{\text {rd }}$ Annual Assembly \& International Conference of the International Institute of Welding, Turkey, pp. $373-380$, 2010. DOI: $10.13140 / 2.1 .4215 .6324$

[22] "OK Autrod 5087", Available at: https://www.esabna.com/ae/en/products/fillermetals/mig-mag-wires-gmaw/aluminium-wires/ok-autrod-5087.cfm [Accessed: 14-072020]

[23] "OK Autrod 4043", Available at: https://www.esab.co.uk/gb/en/products/fillermetals/mig-mag-wires-gmaw/aluminium-wires/ok-autrod-4043.cfm. [Accessed: 14-072020]

[24] ISO 25239-4:2020, Friction stir welding — Aluminium — Part 4: Specification and qualification of welding procedures 